\title{
К ВОПРОСУ О ДОХОДАХ, НА КОТОРЫЕ НЕВОЗМОЖНО ОБРАТИТЬ ВЗЫСКАНИЕ В ИСПОЛНИТЕЛЬНОМ ПРОИЗВОДСТВЕ
}

\section{ON THE QUESTION OF INCOME THAT CANNOT BE FORECLOSED IN THE ENFORCEMENT PROCEEDINGS}

N. Sheremeteva N. Sheremeteva

Summary: In the content of this article, the authors consider the extremely significant and topical issue today about the impossibility of foreclosure on certain types of the debtor's income within the framework of enforcement proceedings. The authors agree that in some part the statutory prohibition violates the rights of creditors, and certain types of income from the specified list in the current Russian law on enforcement proceedings, in order to resolve the existing problem, should be collected from debtors.

Keywords: income, impossibility of collection, debtor, creditor, court decision, enforcement proceedings, amendments, violation of law, private property.
Шереметьева Наталья Владимировна старший преподаватель, ФГБОУ ВО «Владивостокский государственный университет экономики и сервиса», 2. Владивосток; помощник судьи, Арбитражный суд Приморского края nata-sheremet@mail.ru

Шереметьева Нина Геннадьевна

ФГБОУ ВО «Владивостокский государственный университет экономики и сервиса», г. Владивосток sheremeteva_99@inbox.ru

Аннотация: В содержании настоящей статьи авторами рассматривается крайне значимый и актуальный на сегодняшний день вопрос 0 невозможности обращения взыскания на отдельные виды дохода должника в рамках исполнительного производства. Авторы сходятся в едином мнении о том, что в некоторой части регламентированный законодательно запрет нарушает права кредиторов, и отдельные виды дохода из указанного перечня в действующем российском законодательстве $0 б$ исполнительном производстве, с целью разрешения существующей проблемы, должны взыскиваться с должников.

Ключевые слова: доходы, невозможность взыскания, должник, кредитор, судебное решение, исполнительное производство, изменения, нарушение права, частная собственность.
$\mathrm{B}$ настоящее время прослеживается четко выраженная тенденция стремления должников уклониться от исполнения вступившего в законную силу решения судов о взыскании с них сумм задолженности в рамках возбужденного исполнительного производства Федеральной службы судебных приставов: так, согласно официальным отчетным статистическим данным, представленным на официальном сайте вышеуказанного органа ежегодно свыше 30000 судебных решений не могу быть исполнены, в связи с отсутствием у должников имущества и доходов, в отношении которых в соответствии с положениями действующего российского законодательства может быть обращено взыскание [1].

Именно в этой связи особенно остро встает вопрос о необходимости пересмотра действующего российского законодательства об исполнительном производстве в части запрета взыскания на некоторые виды дохода должника с целью восстановление нарушенных прав кредитора и своевременного исполнения судебного решения, вступившего в законную силу: насколько это реально и допустимо на сегодняшний день и предстоит ответить нам в рамках настоящего исследования.

Так, в содержании положений статьи 110 действующего российского закона, регламентирующего порядок реализации исполнительного производства на территории нашего государства приведен перечень всевозможных видов доходов, принадлежащих должнику, на которые не может быть обращено взыскание [2]. Приведенный в указанном нормативном правовом акте перечень носит исключительно исчерпывающий характер, включая в себя следующее:

- денежные суммы, выплаченные в качестве компенсации вреда причиненного здоровью должника;

- денежные суммы, выплаченные в качестве компенсации вреда в связи со смертью кормильца должника;

- денежные суммы, выплаченные в качестве компенсации вреда здоровью должника, (а именно увечий, ранений, травм, контузий), полученного при служебной необходимости, а также членам семьи (в числе которых находится должник) погибших при исполнении служебных обязанностей лиц;

- компенсационные выплаты лицам, пострадавшим в результате происхождения техногенных и радиационных катастроф (должнику), которые начисляются из средств бюджета Российской Федерации; региональных бюджетов, а также местных бюджетов;

- компенсационные выплаты лицам (должнику), которые начисляются на их счет в связи с осущест- 
влением ими ухода и присмотра за нетрудоспособными гражданами;

- ежемесячные выплаты, начисляемые лицам (должнику) в связи с компенсацией его расходов на приобретение медицинских лекарственных препаратов, проезда в общественном транспорте, а также иные;

- алименты, а также выплаты детям, в период розыска их родителей, признанных по решению суда, вступившего в законную силу, без вести отсутствующими;

- компенсационные выплаты, начисляемые работникам (должнику) в соответствии с положениями действующего российского трудового законодательства, а также в связи с переводом на другую должность, командировкой, в связи с изнашиванием инструмента, которые принадлежит на праве частной собственности работнику; в связи с рождением детей, гибелью родных, регистрацией брака в органа записи гражданского состояния;

- страховое обеспечение, за исключением различных видов пенсий (по старости и инвалидности), а также выплат в период нетрудоспособности;

- пенсии, выплачиваемые в связи с потерей кормильца из средств бюджета Российской Федерации и доплаты к ним из средств региональных бюджетов;

- пособия на детей, выплачиваемые должнику из средств бюджета Российской Федерации и доплаты к ним из средств региональных бюджетов, а также местного бюджета;

- федеральный и региональный материнский капитал;

- денежные суммы единовременной помощи, выплачиваемые в связи стихийными бедствиями, террористическим актом, смертью члена семьи, гуманитарной помощью, за содействие расследованию (в том числе выявлению, пресечению и раскрытию) преступных деяний террористической направленности;

- полная или частичная денежная сумма, выплачиваемая должнику в счет компенсации неиспользованных путевок в санитарно-курортные учреждения (исключения тут составляют те денежные средства, которые были выплачены в счет компенсации путевок туристических);

- денежные суммы, выплаченные должнику в счет компенсации проезда к месту лечения и, соответственно, обратно;

- доплата по 10000 (десять тысяч) рублей, выплачиваемая на основании волеизъявления Президента Российской Федерации за каждого ребенка в период распространения коронавируса на территории российского государства [3].

Таким образом, становится совершенно очевидно, что отечественный законодатель в указанный перечень включил все то множество денежных выплат, носящих сугубо социально ориентированный характер: иными словами, ограничения по обращению взыскания в рамках исполнительного производства распространяются исключительно на те виды дохода должника, которые выплачиваются ему за счет средств различных бюджетов в сложившейся сложной жизненной ситуации. Полагаем, что при таком раскладе он преследовал именно цель защиты социальных прав должников, которые попали в трудную жизненную ситуации, и выплачиваемые им денежные средства попросту помогают им выжить в ней. Именно поэтому обратить взыскание на них в рамках исполнения вступившего в законную силу судебного решения не представляется возможным, что отчасти с позиции социально-демократического и правого государства, которым провозглашена Российская Федерация, в конституционных положениях.

Однако, насколько же справедливым это может считаться по отношению кредиторам? Ведь многие из них также находятся в сложной жизненной ситуации, и при этом остаются по сути лишенными возможности получить денежные средства, причитающие им от должника на законных основаниях (преимущественно здесь мы ведем речь о ситуациях, при которых со стороны должника был причинен вред здоровью кредитору, или быть может, когда по вине должника произошла гибель его родственника). Ведь в подобного рода ситуациях кредитор ничем не отличается от должника, только при этом последний, как правило, сам виноват в том, что на нем лежит бремя юридической ответственности перед кредитором, выраженная в финансовом эквиваленте. И невозможность взыскания с него денежных выплат, носящих социально-ориентированный характер в пользу кредитора позволяет должнику улучшить свои жизненные обстоятельства, а кредитор (и без того лицо, являющееся потерпевшим), вынуждено претерпевать неблагоприятные последствия, неизбежно возникающие в связи с неисполнением судебного решения, вступившего в законную силу.

В этой связи вполне логичным и оправданным представляется снятие установленных законодательно ограничений по недопустимости обращения взыскания на имущество должника, в выше названном перечне, в той ситуации, когда задолженность перед кредитором возникла в связи с причинением последнему вреда здоровью или смерти в результате совершения должником неправомерных (незаконных) действий. Это позволило бы восстановить баланс справедливости. При этом важно понимать, что по-прежнему логичным следует оставить установленное законом ограничение в отношение выплат, производимых на счет лица, являющегося должником для содержания и финансового обеспечения несовершеннолетних детей (в частности, речь, прежде всего, 
идет об алиментах, пособиях (например, единовременном пособии при рождении ребенка, ежемесячных выплатах на содержание ребенка в возрасте до полутора лет (и далее, если речь идет о так называемых выплатах для малоимущих до достижения их детей возраста 7 лет («Путинские выплаты» в обиходе обывателя), а также все множество иных, ведь в таком случае эти выплаты принадлежат не должнику, а его детям (а он лишь является их уполномоченным законным представителем).

Еще одна проблема связывается нами с невозможностью определения вида дохода на счету должника Федеральной службой судебных приставов: иными словами, служащие данного органа лишены возможности заблаговременно понимать относятся ли денежные средства, поступившие на счет должника, который находится под арестом, к видам доходов, в отношении которых не допускается взыскание или нет. Автоматически денежные средства, как правило, списываются в счет погашения существующей задолженности, и только после должник сам вынужден доказывать, что данные денежные средства не могли быть взысканы в рамках исполнительного производства на основании действующего российского законодательства. Данный процесс является достаточно трудоемким и долговременным, в связи с чем, должник лишен возможности распоряжаться денежными средствами, попав и без того в сложную жизненную ситуации (а это может поставить под угрозу его жизнь и здоровье, а также благосостояние и здоровье близких и родных ему лиц).

Полагаем, такое положение дел заведомо нарушает права граждан, являющихся должниками, в силу чего в закон должны быть внесены изменения, обязывающие судебных приставов-исполнителей до момента списания денежных средств уточнять, относятся ли поступивших денежные средства к установленному перечню в законе или нет (для этого будет уместно обязать отправителя денежных средств назначение платежа).

В завершении настоящего исследования укажем, что предложенные нами способы разрешения существующих проблем позволят не только их разрешить, но сделать весомые шаги в укреплении позиций российского государства как социального, демократического и правового.

\section{ЛИТЕРАТУРА}

1. Отчет о результатах деятельности Федеральной службы судебных приставов за период с 2015 по 2019 годы [Электронный ресурс] 0фициальный сайт Федеральной службы судебных приставов. URL: http://fssp.gov.ru/ [дата обращения:03.11.2020].

2. 06 исполнительном производстве: Федеральный закон от 02.10.2007 № 229-Ф3 (ред. 0т 31.07.2020) [Электронный ресурс] доступ из справоч.- правовой системы «Гарант». - Загл. с экрана.

3. «0 дополнительных мерах социальной поддержки семей, имеющих детей: Указ Президента Российской Федерации от 07.04.2020 № 249 [Электронный ресурс] доступ из справоч.- правовой системы «Гарант». - Загл. с экран

○ Шереметьева Наталья Владимировна (nata-sheremet@mail.ru), Шереметьева Нина Геннадьевна (sheremeteva_99@inbox.ru).

Журнал «Современная наука: актуальные проблемы теории и практики» 